https://helda.helsinki.fi

\title{
Traditional Ecological Knowledge
}

\section{Casi, Corinna}

Helsinki University Press

2021

Casi , C , Guttorm , H \& Virtanen , P K 2021, Traditional Ecological Knowledge . in C P Krieg \& R Toivanen (eds), Situating Sustainability: A Handbook of Contexts and Concepts . Helsinki University Press, Helsinki , pp. 181-194 . https://doi.org/10.33134/HUP-14

http://hdl.handle.net/10138/338625

https://doi.org/10.33134/HUP-14

cc_by_nc

publishedVersion

Downloaded from Helda, University of Helsinki institutional repository.

This is an electronic reprint of the original article.

This reprint may differ from the original in pagination and typographic detail.

Please cite the original version. 


\title{
Traditional Ecological Knowledge
}

\author{
Corinna Casi, Hanna Ellen Guttorm \\ and Pirjo Kristiina Virtanen \\ University of Helsinki and Helsinki Institute \\ of Sustainability Science
}

\begin{abstract}
Traditional ecological knowledge (TEK) refers to a body of knowledge, practices, and ideas transmitted and (re)generated orally and non-verbally in diverse forms from generation to generation. It is constantly changing and being updated. TEK is rich among several communities, but we will situate our cases in the Amazonian and Arctic Indigenous contexts. We will also discuss the limits of TEK in sustainability science, which include its truth-value and legitimacy. As it originates from different traditions, experiences, and language structures, it is challenging to systematize. Recently, however, TEK has been recognized in a more inclusive way, and
\end{abstract}

How to cite this book chapter:

Casi, C., H. E. Guttorm and P. K. Virtanen. 2021. 'Traditional Ecological Knowledge'. In Situating Sustainability: A Handbook of Contexts and Concepts, edited by C. P. Krieg and R. Toivanen, 181-194. Helsinki: Helsinki University Press. DOI: https://doi.org/10.33134/HUP-14-13. 
traditional knowledge holders have been taken as collaborators to scientific projects. Therefore, various local communities have been able to contribute to science with their views and knowledge of the social history and presence of specific places, which are rapidly changing due to climate change and global warming. This has also offered better-situated and multidimensional understandings of complex and dynamic ecosystems. The inclusion of TEK can thus bring better-informed results, improve our understanding of environmental situations, and eventually contribute to greater sustainability.

\section{Interconnectedness in Traditional Ecological Knowledge}

This chapter introduces the notion of Traditional Ecological Knowledge (TEK) and shows its constantly changing local contents and connections. Our examples of the TEK and its use for policy making and academia come from Indigenous contexts in the Arctic and in the Brazilian Amazon. The cases show the notion of situated sustainability inclusive to both humans and other-than-human actors within certain localities. Our point is that TEK contributes to a complete picture of complex sustainability issues, and it can make a policy-making process more inclusive and better-informed.

Traditional ecological knowledge (TEK)—or local ecological knowledge (LEK), as it is sometimes known-refers to a body of knowledge, practices, and ideas transmitted and (re)generated orally and non-verbally in various forms from generation to generation. It started to receive attention in the 1980s when local species identifications and terminologies documentation were carried out-for instance, in ethnobiology. Several investigations also focused on the human understanding of ecological processes and interrelations in the field of human ecology, but TEK is much broader than environmental knowledge and comprehension of natural phenomena (McGregor 2004). The applied ecologist Fikret Berkes has defined it as 'a cumulative 
body of knowledge, practice, and belief, evolving by adaptive processes and handed down through generations by cultural transmission, about the relationship of living beings (including humans) with one another and with their environment' (Berkes 1999/2012: 7).

Even if there is no clear definition for TEK, it is commonly understood that 'traditional' in the term 'traditional ecological knowledge' does not refer to something only from the past (Battiste and Youngblood Henderson 2000/2012: 46); rather, it is about wisdom acquired on a long-term scale, constantly changing and being updated (Berkes 1999/2012: 5). Martha Johnson (1992), the former executive director of the Dene Cultural Institute in the Northwest Territories in Canada, adds that, despite its strong connection with the past, TEK 'is both cumulative and dynamic, building upon the experience of earlier generations and adapting to the new technological and socio-economic changes of the present' (Johnson 1992: 4). TEK thus binds together generations of the past, the present and the future (Porsanger and Guttorm 2011: 18).

TEK is not simply a descriptive body of literature, and nor can it be categorized into separate fields, such as biology, geography, or chemistry. It is holistic, a 'way of life, a relationship that requires doing' (McGregor 2004: 396), and practical experience (Porsanger and Guttorm 2011: 18). TEK is connected to a specific place, and thus it is a situated knowledge (Berkes 1999/2012; Lauer and Aswani 2009; Weir 2009). One cannot be an expert in TEK by studying it without practising, living, and experiencing it personally, as it is possible to do with many types of Western sciences (LaDuke 1997: 35; McGregor 2004: 394). Thus, TEK is empirical, practical knowledge, and cannot be separated from the environment where it is produced. Furthermore, as Rebecca Tsosie (1996: 286-87) claims, TEK has a lot to teach about sustainable living, because it is the spontaneous outcome of the relationship of Indigenous people with the environment, their connection through generations across time, as well as respect for the natural life cycle. In other words, it is often about an 
ecologically and socially sustainable way of life, connected to every decision, and policies also (understanding how life is sustained by humans and the environment together).

Even if TEK is rich among several communities (both Indigenous and non-Indigenous), we focus here on Indigenous contexts. Different TEKs can reflect different social systems that define what exists in the world (ontologies) and how knowledge is produced and what can be known (epistemologies). Values (axiologies) also affect the construction of TEK (Battiste and Youngblood Henderson 2000/2012; Berkes 1999/2012; Weiss, Hamann and Marsh 2013). Furthermore, these affect how TEK can be studied, used, and presented. Anishinaabe scholar Deborah McGregor (2004: 394-95) has argued that there are Indigenous and non-Indigenous views on Indigenous TEK. The non-Indigenous attempts at defining TEK focus on the content of the knowledge and how it is conveyed. Meanwhile, she notes that non-Indigenous views on TEK are often partial and incomplete, and even carry colonial attitudes toward Indigenous peoples. According to McGregor, Indigenous approaches underline connectedness, action, and the fact that human beings cannot be considered in isolation from their environment (2004). The Indigenous notion of TEK goes beyond the physical landscape; it refers to social relationships with living beings (human and other-than-human), and it is closer to the understanding of 'ecosystem' (Legat, Zoe and Chocolate 1995). Thus, Indigenous peoples view the environment, people, and knowledge inseparably, as a whole, and interconnected with each other (McGregor 2004: 394-95; Roberts 1996: 115). When addressing TEK in dominant languages, Indigenous peoples often use expressions such as 'the Creation' (e.g. the Haudenosaunee and Anishinaabe, First Nations tribes within the province of Ontario, Canada), 'the Earth Mother' (such as the Maori in New Zealand), or 'the land' (Indigenous people in Australia, the Arctic, and Hawaii). Indigenous scholars have argued that TEK is not only knowledge about interconnectedness with the natural environment, but a relationship itself: a 'practiced relationship' (Cajete 2000) and 'the way one relates' (McGregor 2004: 394). 


\section{TEK Among Amazonian and Arctic Indigenous Peoples}

TEK exists in various forms, and so do its learning processes, which are culture-specific. In Indigenous contexts, TEK is connected to Indigenous traditions and cosmologies, and embedded in their languages, as certain relationalities and agencies of other-than-human entities are expressed in the structures and terminologies of local languages. TEK also forms a significant part of Indigenous communities' cultural heritage (Porsanger and Virtanen 2019: 293). Our two cases for situating TEK come from the Amazonian and Arctic Indigenous contexts, namely from the Apurinã, Manchineri, and Sámi communities.

For the Apurinã and Manchineri in Brazilian Amazonia, much of their TEK involves practical knowledge of diverse habitats and local livelihoods, such as fishing; collecting; protecting certain forest patches for animals and plants; use of fire for planting; gardening; selecting; weather forecasting; use of medicinal plants; and moving through the forest and waters. The Arawak-speaking Apurinã and Manchineri peoples-with whom the third author, Pirjo Kristiina Virtanen, has worked since 2003-inhabit the Upper and Central Purus River Basin, Southwestern Amazonia. These peoples came into contact with the dominant society at the end of the nineteenth century, and currently their territories are situated in the states of Acre and Amazonas, Brazil. Their longterm environmental observations, perceptions, assessments, and sensing-emerging from the variety of sounds, smells, and predictions-form the core basis of their TEK. These are often reported and analyzed communally; community members accumulate and contribute to the body of TEK in their own ways. Furthermore, community members provide an important epistemic community (who share the same idea of evidence and how knowledge is produced) to debate possible explanations for the events and for argumentation (Virtanen 2016: 98-100). Meanwhile, there are elemental gender, age, and expertise (such as hunters, healers, and so forth) differences in TEK. These guide the Manchineri and Apurinã subsistence practices. 
From a young age, the Manchineri and Apurinã learn about their generations' long relationships with the plants, trees, animals, rivers, lakes, and other people, while attention is drawn to the interactions and interdependency of these entities. Personal corporal experience and moral issues are crucial in this learning process (Virtanen 2012). Among the Manchineri and Apurinã, an autonomous person knows the practices of care and respect toward other-than-human entities, as well as various practices of communication with them (animals and plants addressed by specific terms). Other-than-human subjectivities, such as so-called animal and plant master (owner) spirits, are thought to act and even draw on humans in harmful ways, if they become disturbed or when forest resources are overconsumed. The spiritual practices of the communities point to these invisible social realities that are inseparable from their ideas of sustainability (Virtanen 2016; 2019). These become explicit in art, such as songs, stories, and geometric designs applied on the human body, ceramics, clothes, beadwork, which for their part, when materialized, can connect humans and specific other-than-human actors.

Long-term observations are crucial for analyzing forest and water resources and broader ecosystems in the Manchineri and Apurinã lands, and their potential required conservation, among others. Both groups have already contributed to the territorial mappings in their demarcated reserves. These state-led projects studied the impacts of the new paved highways in proximity to the Indigenous lands and how to manage the natural resources in the Indigenous lands (e.g. Correia et al. 2006). The participative approach was crucial in the projects, but little has been done to protect the territories and to improve Indigenous peoples' own economic projects on their own terms. Subsequently, so-called ethno-mapping (etnomapeamento) initiatives have also been carried out by Indigenist organizations, and a group of Manchineri and Apurinã community members has been trained as researchers-not only to identify the existing natural resources in the territory but also to produce thematic maps, including culturally and historically valuable places for the community and biodiversity, 
as well as to make future resource management and educational plans (e.g. Almeida, Ochoa and Gavazzi 2016; Bavaresco, Menezes and Miller 2016). The maps can be used as a basis to discuss territorial conflicts, invasions, and required protection and conservation acts.

Among the Sámi-the only recognized Indigenous people in the European Union-who live in the northern parts of Nordic countries and Russia, TEK is defined as 'traditional knowledges and skills' (árbevirolaš dieđut ja máhtut, as in Northern Sámi), which illustrates how it is connected to various practical needs and situations. The concept 'inherited knowledge' (árbediehtu) points to knowledge that is not learnt from books or in formal education, but inherited from generation to generation. Porsanger and Guttorm (2011: 18) define árbediehtu as 'the collective wisdom and skills of the Sámi people used to enhance their livelihood for centuries. It has been passed down from generation to generation, both practically and through work and practical experience. Through this continuity, the concept of árbediehtu ties the past, present, and future together'. TEK in Sámi communities is entangled in livelihoods, such as reindeer herding, fishing, collecting berries, hunting, and traditional handicrafts, as well as moving in the forests, fells, rivers, lakes, and the Arctic sea. For example, in salmon fishing, the knowledge of salmon, its movement, spawning, and needs, as well as knowledge of the Teno river and its changing water level, is very detailed and both transmitted and regenerated through practices, observations, and stories (Guttorm, forthcoming; Joks 2015; Østmo and Law 2018).

TEK in Sámi communities is connected to certain humble dispositions and attitudes of the people to adapt themselves and their practices, which are possible or rational to perform, according to the weather conditions, as well as according to the will of the animals and other non-human actors (e.g. Guttorm, forthcoming; Østmo and Law 2018). Ethical and respectful relationality and reciprocity are displayed by using everything of the animal obtained, and leaving the places in the environment as they were. It also means recognizing and respecting the fact that every animal, 
ealli, has a soul or spirit, as well as emotions, values, goals, and conscious ways of acting, communicating, and taking care. Also, lands are perceived as living entities and active in relation to humans and animals (Helander-Renvall 2016). In reindeer herding, this respect has recently encountered difficulties, as the acts and regulations have made it impossible to follow the multiple ancient habits of respecting nature and non-human beings-for example, the practice of not ever counting the reindeer or ptarmigans (Buljo 2017). In multiple Sámi contexts, the spiritual understanding of animals and other nature objects, as well as the existence of subterranean spirits, is called the 'old religion' (dolos osku), but it can also be called animism, which creates both respect and humility between the mutually interdependent human and other-than-human actors (Helander-Renvall 2010). However, the level on which animism influences practices or the experience of one's relationship to the environment varies both locally and depending on one's livelihood (Porsanger 2007). In current Sámi communities, the sacred practices are gradually recovering, as e.g. the practices of using sieidi stones to ask for good luck in reindeer herding, fishing, or life in general are revitalized.

The traditional knowledges produced by both Amazonian and Sámi Indigenous communities, which often aim to maintain the balance between humans and other-than-humans, are still largely disvalued in the schooling processes of dominant societies. For many Indigenous peoples, a long period of assimilation has meant tragedies because of devaluing native philosophies, large-scale economic actions expanding in their territories, missionaries' attempts to convert the native peoples to different Christian movements, and new values introduced by the dominant culture. Some peoples' tragedies have been greater than others: several peoples have become extinct, and numerous Indigenous languages are no longer spoken because of oppression, but TEKs-taught informally and since childhood-are important for Sámi, Manchineri, and Apurinã societies, and among many other Indigenous peoples. There are various solutions for bridging TEK and conventional scientific knowledge, and considering how they can become 
mutually beneficial. Indigenous peoples' long-term observations can advance scientific knowledge-for example, when planning resource management and nature conservation. Thus, they can also be useful for policy making.

\section{Potentials and Limits of TEK in Sustainability Issues and Science}

TEK offers more multidimensional views of complex ecosystems and more sustainable outcomes. As a concept and content, TEK is widely used in anthropological, biological, cultural, and social research (see e.g. Kimmerer 2015; Lam et al. 2020; Lauer and Aswani 2009; Nadasdy 2011). However, in conventional Western science, TEK is often considered to lack a quantitative systematic approach of measurement, and thus it is not easily recognized as valid knowledge. Its systematization is also viewed as challenging because TEK originates from different traditions, language structures, and experiences. In addition, TEK is often considered to exist only qualitatively and as embodied skills, not in a textual form. That is why the position afforded TEK in many scientific investigations is mostly reduced either to producing new scientific hypotheses, testing, or interpreting scientific results (Johnson et al. 2016; Joks and Law 2017). Yet, Sámi scholar, Mikkel Nils Sara, has noted regarding scientific research on reindeer herding '[n] or has scientific research on reindeer produced results that add new insights to or contradict traditional knowledge' (Sara 2009: 162).

The limits of engaging with TEK on sustainability issues in policy making include its truth-value and recognition in academia, as well as in economic and development projects. Recently, however, Indigenous peoples have increasingly become collaborators in scientific projects and conservation efforts, and TEK has become acknowledged in a more inclusive way (Johnson et al. 2016). Co-production of knowledge methods have offered better-situated and multidimensional understandings of complex sustainability issues, such as dynamic ecosystems, which are rapidly transforming due to climate change and global warming. TEK can offer 
different descriptions of events-for instance, a more practical view for the field of biosciences to produce their measurements and modelling. Local communities have been able to contribute to science, drawing from their practical experiences and views on environmental history, conservation practices, resource management, and knowledge of specific places (Berkes 1999/2012; Chilisa 2017; McGregor 2014). The synthesis and integration of different TEKs and scientific research can improve our understanding of environmental situations, produce better-informed results, increase our understanding of different values in knowledge-production, and eventually lead to greater and more inclusive sustainability discussions and outcomes (Lam et al. 2020; Tengö et al. 2014; Virtanen, Siragusa and Guttorm 2020). However, the challenge still often remaining is that the earlier epistemological hierarchies lead the analytical thinking and eventual policy-making decisions (cf. Hakkarainen et al. 2020).

Due to the close tie between TEK and the people who hold this knowledge, according to LaDuke, the people who experience and 'who live by this knowledge have the intellectual property rights to it' (LaDuke 1997: 37). Ultimately, an unsolved issue that requires more attention internationally is the lack of laws and regulations on TEK, as legal protection of Indigenous peoples' TEK that has been commercially exploited for years (Porsanger and Guttorm 2011: 35-36). Consequently, there is a need to consensually recognize the Indigenous peoples' legitimacy over their TEK and to provide it legal protection. A successful example is represented by the UN Convention on Biological Diversity (CBD), where the Code of Ethical Conduct was approved in 2010. It acknowledges the preservation of traditional knowledge and recognizes the sustainable use of the natural resources and the territories by the Indigenous peoples (CBD Code of Conduct 2010; Porsanger and Guttorm 2011: 36-37). In the context of biodiversity convention, however, an unsolved question is also how to remunerate the holders of TEK fairly for their contribution to the world's biodiversity. The greatest danger at this moment for regeneration of TEK are economic development projects that alter and destroy the local ecosystems 
and Indigenous peoples' environments. When TEK can no longer be reproduced, created, and used in practice, its possible future revival becomes significantly uncertain.

\section{Acknowledgements}

Corinna Casi thanks the University of Helsinki, the University of Lapland and the ValueBioMat project, financed by the Strategic Research Council-Academy of Finland, for the academic support.

Hanna Ellen Guttorm thanks Sámi relatives, friends, colleagues and ancestors for the multiple wisdom, as well as HELSUS (Helsinki Institute of Sustainability Science) and the Faculty of Arts, University of Helsinki, and the Kone Foundation for the financial support.

Pirjo Kristiina Virtanen is grateful for her long-term research collaborators in Amazonia, Sápmi, and Finland; for the financial support, she would like to thank the Academy of Finland (grant agreement nr. 297161) and the University of Helsinki.

\section{References}

Almeida, M. I., M. L. Ochoa and R. A. Gavazzi. 2016. Plano de Gestão da Terra Indígena Mamodate. Rio Branco: Comissão Pró-Índio do Acre. Battiste, M. and J. S. Youngblood Henderson. (2000) 2012. Protecting Indigenous Knowledge and Heritage. A Global Challenge. Saskatoon: Purich.

Bavaresco, A., M. Menezes and R. Miller. 2016. Formação para Gestão territorial e ambiental. Brasília: IEB.

Berkes, F. (1999) 2012. Sacred Ecology. 3rd ed. New York, NY: Routledge. Buljo, M. R. 2017. Vuoinnalašvuohta sámi biebmovieruin / Åndelig tenkning i samiske mattradisjoner. Vuoinnalaš Vierut/ Åndelige tradisjoner og kulturelle praksiser seminar. Kautokeino: Sámi University of Applied Sciences.

Cajete, G. 2000. Native Science: Natural Laws of Interdependence. Santa Fe, NM: Clear Light.

CBD Code of Conduct 2010. 2010. Convention on Biological Diversity Tkarihwaié:ri Code of Ethical Conduct to Ensure Respect for 
the Cultural and Intellectual Heritage of Indigenous and Local Communities Relevant to the Conservation and Sustainable Use of Biological Diversity. Nagoya, Japan: Secretariat of the Convention on Biological Diversity, 18-29 October 2010. Accessed 3 April 2020. https://www.cbd.int/traditional/code/ethicalconduct-brochure -en.pdf.

Chilisa, B. 2017. 'Decolonising Transdisciplinary Research Approaches: An African Perspective for Enhancing Knowledge Integration in Sustainability Science.' Sustainability Science, 12 (5): 813-27.

Correia, C., E. Lozano, J. Vivan and W. Araújo. eds. 2006. Etnozoneamento da Terra Indígena Mamoadate. Rio Branco: SEMA-ACRE.

Guttorm, H. (forthcoming). 'Becoming Earth: Rethinking and (Re-)Connecting with the Earth, Sámi lands and relations'. In Bridging Cultural Concepts of Nature: Indigenous Places and Protected Spaces of Nature, edited by R.-H. Andersson, B. Cothran and S. Kekki. Helsinki: Helsinki University Press.

Hakkarainen, V. T., C. B. Anderson, M. Eriksson, C. J. van Riper, A.-I. Horcea-Milcu and C. M. Raymond, 2020. 'Grounding IPBES Experts' Views on the Multiple Values of Nature in Epistemology, Knowledge and Collaborative Science. Environmental Science \& Policy, 105: 11-18.

Helander-Renvall, E. 2010. 'Animism, Personhood and the Nature of Reality: Sami Perspectives'. Polar Record, 46 (1): 44-56.

Helander-Renvall, E. 2016. Sámi Society Matters. Rovaniemi: Lapland University Press.

Johnson, J. T., R. Howitt, G. Cajete, F. Berkes, R. L. Pualani and A. Kliskey. 2016. 'Weaving Indigenous and Sustainability Sciences to Diversify our Methods'. Sustainability Science, 11: 1-11.

Johnson, M. 1992. LORE: Capturing Traditional Environmental Knowledge. Ottawa, ON: Dene Cultural Institute and International Development Research Centre.

Joks, S. 2015. 'Laksen trenger ro'. Tilnorming til tradisjonelle kunnskaper gjennom praksiser, begreper og fortellinger fra Sirbmá-området. Tromso: UiT, Norges Arktiske Universitet.

Joks, S. and J. Law. 2017. 'Sámi Salmon, State Salmon: TEK, Technoscience and Care'. The Sociological Review, 65 (2): 150-71.

Kimmerer, R. W. 2015. Braiding Sweetgrass: Indigenous Wisdom, Scientific Knowledge and the Teachings of Plants. Minneapolis, MN: Milkweed Editions. 
LaDuke, W. 1997. 'Voices from White Earth: Gaa-waabaabinganikaag. In People, Land and Community, edited by H. Hannum, 22-37. Great Barrington, MA: E. F. Schumacher Society.

Lam, D. P. M., E. Hinz. D. J. Lang, M. Tengö, H. von Wehrden and B. Martín-López. 2020. 'Indigenous and Local Knowledge in Sustainability Transformations Research: A Literature Review'. Ecology and Society, 25 (1): 3. Accessed 3 March 2020. https://doi.org/10.5751/ES $-11305-250103$.

Lauer, M. and S. Aswani. 2009. 'Indigenous Ecological Knowledge as Situated Practices: Understanding Fishers' Knowledge in the Western Solomon Islands'. American Anthropologist, 111: 317-29.

Legat, A., S. A. Zoe and M. Chocolate. 1995. 'The Importance of Knowing. In NWT Diamonds Project Environmental Impact Statement, Vol. 1, Apps. Vancouver: BHP Diamonds Inc.

McGregor, D. 2014. 'Traditional Knowledge and Water Governance: The Ethic of Responsibility'. AlterNative: International Journal of Indigenous Peoples, 10 (5): 493-507.

McGregor, D. 2004. 'Coming Full Circle: Indigenous Knowledge, Environment, and our Future'. American Indian Quarterly, 28 (3-4): 385-410.

Nadasdy, P. 2011. 'Application of Environmental-Knowledge. The Politics of Constructing Society/Nature'. In Knowing Nature: Conversations at the Intersection of Political Ecology and Science Studies, edited by M. Goldman, P. Nadasdy and M. Turner, 129-33. Chicago, IL: University of Chicago Press.

Østmo, L. and J. Law. 2018. 'Mis/translation, Colonialism and Environmental Conflict'. Environmental Humanities, 10 (2): 349-69.

Porsanger, J. 2007. Bassejoga čáhci: Gáldut nuortasámiid eamioskkoldaga birra álgoálbmotmetodologiijaid olis. Kárášjohka: Davvi Girji.

Porsanger, J. and G. Guttorm, eds. 2011. 'Working with Traditional Knowledge: Communities, Institutions, Information, Systems, Law and Ethics', Dieđut 1. Guovdageaidnu: Sámi University College.

Porsanger, J. and P. K. Virtanen. 2019. 'Introduction: A Holistic Approach to Indigenous Peoples' Rights to Cultural Heritage'. AlterNative: International Journal of Indigenous Peoples, 15 (4): 289-99.

Roberts, K. 1996. 'Circumpolar Aboriginal People and Co-Management Practice: Current Issues in Co-Management and Environmental Assessment'. Calgary, AB: Arctic Institute of North America and Joint Secretariat-Inuvialuit Renewable Resources Committees; Arctic Institute of North America, University of Calgary. 
Sara, M. N. 2009. 'Siida and Traditional Sámi Reindeer Herding Knowledge'. Northern Review, 30: 153-78.

Tengö, M., E. S. Brondizio, T. Elmqvist, P. Malmer and M. Spierenburgh. 2014. 'Connecting Diverse Knowledge Systems for Enhanced Ecosystems Governance: The Multiple Evidence Based Approach'. Ambio, 43: 579-91.

Tsosie, R. 1996. 'Tribal Environmental Policy in an Era of Self-Determination: The Role of Ethics, Economics, and Traditional Ecological Knowledge. Vermont Law Review, 21: 286-87.

Virtanen, P. K. 2012. Indigenous Youth in Brazilian Amazonia: Changing Lived Worlds. New York: Palgrave Macmillan.

Virtanen, P. K. 2016. 'The Death of the Chief of Peccaries - The Apurinã and Scarcity of Forest Resources in Brazilian Amazonia'. In HunterGatherers in a Changing World, edited by V. Reyes-García and A. Pyhälä, 91-105. New York, NY: Springer.

Virtanen, P. K. 2019. "Ancestors' Times and Protection of Amazonian Biocultural Indigenous Heritage'. AlterNative: International Journal of Indigenous Peoples, 15 (4): 330-39.

Virtanen, P. K., L. Siragusa and H. Guttorm. 2020. 'Introduction: Indigenous Conceptualizations of 'Sustainability". Current Opinion in Environmental Sustainability, 43: 77-82.

Weir, J. K. 2009. Murray River Country: An Ecological Dialogue with Traditional Owners. Canberra: Aboriginal Studies Press.

Weiss, K., M. Hamann and H. Marsh. 2013. 'Bridging Knowledges: Understanding and Applying Indigenous and Western Scientific Knowledge for Marine Wildlife Management'. Society and Natural Resources, 26 (3): 285-302. 